\title{
Compensatory growth and feed restriction in marine shrimp production, with emphasis on biofloc technology
}

\author{
Julio Cesar Maciel $^{1}$ • Claire Juliana Francisco ${ }^{2}$. \\ Kleber Campos Miranda-Filho ${ }^{1}$
}

Received: 18 February 2017 / Accepted: 9 October 2017 / Published online: 16 October 2017

(C) Springer International Publishing AG 2017

\begin{abstract}
In Brazil, studies and production of penaeid shrimp in a biofloc technology (BFT) system are recent, but the results point to a promising future. Research with feed restriction inducing compensatory growth in shrimps has been shown to be a technique that allows a saving of around $25 \%$ in the use of feed for shrimp production. It also allows the reduction of costs with salaries and adapts shrimp farming to the world demand for environmentally friendly production, with the reduction of nitrogen and phosphorus levels in its effluents, as well as lower water use in shrimp farming. In crustaceans, it has been shown that after a period of feed restriction, the animals show a pronounced compensatory growth when they return to a sufficient food source. Studies with the penaeid shrimp Litopenaeus vannamei reported the ability of the species to obtain a complete compensatory growth after short feeding periods (1 to 3 days) followed by feeding; These short periods of fasting presented a greater efficiency in the feed conversion besides the decrease in the concentration of phosphorus present in the aquatic environment, coming from the excreta. The adoption of a restriction program in the feeding using BFT may contribute to a reduction in operating costs, reduction of metabolic nutrients dissolved in water, and, consequently, an increase in the number of cycles in which the same water can be reused for production reducing production costs and improving productivity indices in shrimp farming.
\end{abstract}

Keywords Aquaculture $\cdot$ Fasting $\cdot$ Litopenaeus vannamei $\cdot$ Penaeid shrimp

Kleber Campos Miranda-Filho

kmiranda2010@ufmg.br; kleber08@gmail.com

1 Departamento de Zootecnia, Laboratório de Aquacultura (LAQUA), Escola de Veterinária, Universidade Federal de Minas Gerais (UFMG), Av. Pres. Antônio Carlos, 6627, Pampulha, Belo Horizonte, MG 31270-901, Brazil

2 Instituto de Biociências, Universidade Estadual Paulista (UNESP), Rua Prof. Dr. Antonio Celso Wagner Zanin, s/no, Botucatu, SP 18618-689, Brazil 


\section{Introduction}

Fasting is a practice experienced by various aquatic organisms throughout their life cycle. Wu and Dong (2002a) reported that this food discontinuity depends on factors such as water quality, environmental condition, and even the presence of pathogens in the aquatic environment.

In aquaculture activities, food restriction is a technique considered as stressful, but it has been used as a strategy to guarantee the economy in the use of ration, as well as in the reduction of costs with labor. It is believed that food restriction also contributes to the current worldwide demand for environmentally friendly production, reducing nutrient concentrations (e.g., nitrogen and phosphorus) and organic matter in its effluents (Zhu et al. 2016). Moreover, it is believed that compensatory growth (rapid growth after a period of feed restriction) can be fully achieved by the animals returning to the normal feeding condition (Zhu et al. 2016). According to Fóes et al. (2016), the economy of approximately $25 \%$ in feed use could be obtained with food restriction followed by compensatory growth in marine shrimps.

Shrimp farming is the sector within aquaculture that has the highest growth in production, with emphasis on the marine species Litopenaeus vannamei, commonly known as the Pacific white shrimp, a euryhaline species, which is able to tolerate salinities from 0 to $50 \%$ and is the most cultivated in the world (FAO 2014).

Despite the success of shrimp farming, the activity was considered an environmental villain due to the destruction of natural environments (e.g., marshes, swamps, estuaries, and other coastal environments), the construction of ponds, and the release of untreated effluents into recipient bodies (Crab et al. 2012). In addition, several episodes of considerable losses have been reported in recent years. These losses are mainly related to the pathogen action and depletion of water quality in farming environments (De Schryver et al. 2014).

The search for a sustainable technology and biosafety resulted in the development of shrimp farming in a closed superintensive system, with intense aeration, rich in suspended material, without water renewal, using smaller areas of breeding and utilizing the microbiota present in the environment (by manipulation of the carbon:nitrogen ratio) to control and decrease toxic inorganic nitrogen levels, and as a food source. Such a culture system was called biofloc technology (BFT). Other terms have been created to denote such a system as "zero-exchange aerobic heterotrophic system" (ZEAH) and cultivation in heterotrophic medium (Crab et al. 2012; Avnimelech 2014; Krummenauer et al. 2014). More specifically, the mentioned characteristics of the BFT system allow the formation of macroaggregates, consisting basically of microalgae, nitrifying and heterotrophic bacteria, protozoa, rotifers, metazoans, exoskeletons, feces, exudes, and remains of dead organisms, which are predominantly a heterotrophic and aerobic biota called biofloc (Schryver et al. 2008) that develop in an environment rich in carbon and nitrogen, which are characterized by microorganisms rich in protein and other nutrients (Asaduzzaman et al. 2008; Gao et al. 2012; Krummenauer et al. 2014). As mentioned, the socalled bioflocs are produced naturally, vary in different systems, and can be supplemented as a food source for cultivated organisms like penaeid shrimp (Kuhn et al. 2009; Emerenciano et al. 2012), tilapia (Avnimelech 2014), and mussels (Ekasari et al. 2014).

Historically, BFT shrimp farming is an innovative system of shrimp production developed in the USA in the 1990s, adjusting shrimp farming to increasing environmental pressure to reduce water use (Hopkins et al. 1993). The investigations were focused on the production of L. vannamei with minimal use of water changes and even reuse of water for several cycles, aiming also to reduce the introduction, infestation, and dissemination of viral and bacterial 
epidemics (Lara et al. 2012; Krummenauer et al. 2013). The minimum water exchange in the system is guaranteed by the recycling of the nitrogenous compounds carried out by the bacteria present in the aquatic environment (Avnimelech 2014).

In Brazil, studies and production in BFT are recent, but the results point to a promising future (Wasielesky et al. 2006; Poersch et al. 2006; Emerenciano et al. 2012). In cities that are not in a coastal area, the demand and value for marine food are high. This commercial factor compensates the installation of this system (using low salinity) in areas far from the valued coastal region (Maciel 2013).

Studies by The World Bank (2013) indicate that by the year 1980, only $10 \%$ of fishmeal and fish oil produced in the world were consumed by aquaculture, but in 2010 , this percentage rose to $73 \%$, and by 2030 , it will be imperative to improve food efficiency in the consumption of fish meal for the production of animal feed.

Like all productive activities, scaling up has a detrimental effect on the environment. A productive company should aim at optimizing the use of natural resources and production, producing more and better qualities, reducing environmental impacts, and using the minimum natural resources necessary for its production (Américo et al. 2013) — aquaculture with less use of animal resources for its production, less use of water (non-renewable resource), and with a lower effluent level (Souza et al. 2003).

In this sense, the studies have been conducted to show a real efficiency of the biofloc in reducing the amount of fish meal and oil in the rations for shrimp farming (Scopel et al. 2011; Emerenciano et al. 2012).

\section{Biofloc as a food, compensatory growth, and productivity in marine shrimp farming}

Studies have shown that the use of biofloc as a food contributed significantly to the growth of L. vannamei. Emerenciano et al. (2012), working with a nursery of Farfantepenaeus brasiliensis, reported the beneficial role of biofloc by improving water quality and shrimp growth when compared to clear-water treatment. These authors concluded that the rich microbiota, mainly protozoa and rotifers, contributed to better shrimp performance, corroborating Thompson et al. (2002) working with Farfantepenaeus paulensis juveniles $(\sim 0.14 \mathrm{~g})$. Kuhn et al. (2009) described that diets containing biofloc (7.8 to $15.6 \%)$ can be used contributing to the growth and survival of $L$. vannamei juveniles $(\sim 0.44 \mathrm{~g})$. These data were supported by Bauer et al. (2012) using 3.5 to $14 \%$ of biofloc in the diets of $L$. vannamei juveniles $(\sim 2.5 \mathrm{~g})$. On the other hand, diets with biofloc inclusion above $25 \%$ resulted in lower growth of $L$. vannamei juveniles $(\sim 0.59 \mathrm{~g})$ and the authors attributed the result to a restriction of the amino acids lysine and methionine and the high ash content in the dry biofloc. Probably, the trace elements present in the biofloc could generate some toxic effect to the animals (Gamboa-Delgado et al. 2017).

But what is the good thing about using biofloc as a food source? We can describe several positive points collected from successive researches. Chamberlain et al. (2001) and Kuhn et al. (2010) described the high crude protein (CP) content in the biofloc (35 to 51 and 38.8 to 40.5\%, respectively), while Emerenciano et al. (2012) and Xu and Pan (2012), also working with $L$. vannamei in $\mathrm{BFT}$, reported $\mathrm{CP}=30.4$ and 27.3 to $31.6 \%$, respectively. Xu and Pan (2012) also highlight the biofloc lipid content from 3.7 to $4.2 \%$, and in addition to supplemental microbial nutrition, these authors reported the production of extracellular enzymes by 
the biofloc facilitating feed utilization and digestion in shrimps. In addition, Ferreira et al. (2015) stated that microbial biofloc can be a source of probiotic Gram-positive bacteria of the genus Bacillus spp., which is very effective in controlling the opportunistic bacteria of the Vibrio genus. Avnimelech (2014) also explains that the probiotic effect is due to a biopolymer (poly- $\beta$-hydroxybutyrate) stored in microbial cells that can depolymerize, releasing butyric acid, an antimicrobial agent. Another interesting point is the biofloc size. According to Ekasari et al. (2014), biofloc $>100 \mu \mathrm{m}$ presented the highest levels of protein (27.8\%) and lipids (7.5\%), while biofloc $<48 \mu \mathrm{m}$ seemed to be the richest in essential amino acids.

In this way, BFT shrimp farming may allow lower feed utilization and also lower crude protein levels, maintaining the quality of the water medium by the absorption of nitrogenous compounds, allowing the same water to be reused for several consecutive production cycles. In addition, new studies with shrimp feed restriction indicate that productive management with periods of no feeding may be a trend in shrimp farming soon (Crab et al. 2007; Wu and Dong 2002a).

Due to spatial and temporal irregularities of food resources in the natural environment, aquatic animals may encounter periods of fasting or malnutrition during their life cycle $\mathrm{CWu}$ and Dong 2002a). This adaptation to food deprivation induces metabolic responses that may vary according to factors such as life stage, seasons, environmental conditions, temperature, and nutritional status of the animals before the period of food deprivation, influencing biological adjustment by increasing or decreasing the effect of feed restriction on animals (Sheridan and Mommsen 1991).

Growth restriction during the period of food deprivation or fasting can be followed by a rapid growth phase when food is restored, known as compensatory growth (Farbridge et al. 1992). This compensatory growth is usually related to an increase in the rate and efficiency of weight gain during the recovery period (Dobson and Holmes 1984).

Compensatory growth may be an internal adjustment mechanism for animals to adapt in many situations of dramatic variations in the environment: It allows the animals to survive through a period of feed restriction and then to experience an accelerated growth trajectory under normal conditions (Ali et al. 2003; Wasielesky et al. 2013). Body energy reserves, such as lipids, have been considered as responsible for the induction of compensatory growth. Decrease of body lipids and proteins depends on different factors such as the species, size, development phase, duration of the food restriction, and nutritional quality of the food ingested, among others (Wang et al. 2000).

Among aquatic animals, compensatory growth has been most commonly studied in fish: hybrid sunfish (Hayward et al. 2000); several species of fish (Ali et al. 2003); Nile tilapia Oreochromis niloticus (Wang et al. 2009; Ali et al. 2016); gilthead sea bream Sparus aurata (Bavcevic et al. 2010; Peres et al. 2011), Asian catfish Pangasius bocourti (Jiwyam 2010); little research has been done with mollusks, such as scallop Argopecten irradians (Auster and Stewart 1984), and crustaceans, such as Chinese shrimp Fenneropenaeus chinensis (Wu et al. 2000, 2001a, b), Pacific white shrimp L. vannamei (Wasielesky et al. 2013; Zhu et al. 2016), and crayfish Cherax quadricarinatus (Stumpf and Greco 2015).

Studies have shown that during the absence or reduction of food, fish use hormonal and metabolic strategies to survive, causing a decrease in the size of the gastrointestinal tract and liver as a consequence (Souza et al. 2003). When the feed is normalized, the physiological processes are reestablished. Fish use food primarily to meet energy needs in maintaining vital processes by restoring tissue catabolism, and only after that, the rest is used for growth (Souza et al. 2003). 
Studies on feed restriction in fish demonstrate that a feedback strategy with hyperphagia can restore normal fish growth after a period of decreased weight gain and length, which may be more pronounced the longer the feed restriction time (Arauco and Costa 2012). This survival strategy can be used to obtain better zootechnical indices for fish farming, because studies indicate that the adoption of joint strategies of feeding practices that meet the nutritional requirements of fish can maximize the effect of compensatory growth.

In crustaceans, it has been shown that after a period of feed restriction, they exhibit a pronounced compensatory growth when they return to a sufficient food source (Wu et al. 2000, $2001 \mathrm{a}, \mathrm{b})$. But what is the limit to this compensation? Wu et al. (2001a), working with juveniles of $F$. chinensis ( $\sim 2.189 \mathrm{~g}$ ) during 10 days of feed restriction (fed 4 to $12 \%$ of body weight per day) and then feeding them ad libitum under a 30-day recovery period, reported that $12 \%$ of the group was able to regain body weight in comparison with the control group. Cycles of starvation and refeeding, such as 1:4, 2:8, 4:16, and 8:32, were tested by Wu and Dong (2002a), and the authors reported that the shrimp subjected to the different cycles had greater weight gain than the control group (fed ad libitum continously). However, after 32 days of experiment, none of the cycles reached the same body weight as the control group.

In studies with L. vannamei, Lin et al. (2008) reported that this species was able to obtain a complete compensatory growth ( 3 to 9 days) from the reestablishment of feeding after short periods of fasting (1 to 3 days). Likewise, studies with L. vannamei in China found that feed conversion efficiency and mean protein efficiency for groups of shrimp subjected to short periods of feed restriction ( 1 to 3 days) were significantly better than those of the control groups, suggesting that after short periods of feed deprivation, with return to normal feed, there is potential to increase digestion and nutrient uptake by shrimp (Zhu et al. 2016). Comoglio et al. (2004) reported that L. vannamei $(\sim 0.998 \mathrm{~g})$ was able to survive 16 days without food and after 9 days of fasting, the survival decreased to $65 \%$. In another study, L. vannamei ( $\sim 8.18 \mathrm{~g}$ ) had been starved for 7 to 28 days with survival from 100 to $59 \%$ and lost of body weight of 3.2 to $10.4 \%$, respectively. Shrimps starved for 14 days had three stages of modulation of gene expression related to immunity (Lin et al. 2012).

Some specific genetic aspects and physiological responses related to low feeding have been described. Gene expression induced by starvation and refeeding also changes muscle metabolism and growth rate and sometimes can impair muscle growth (Hornick et al. 2000; Hagen et al. 2009). Thus, methods for maximizing growth have been tested for many years in aquaculture, i.e., the use of fasting conditions that result in low growth rate followed by refeeding, when many organisms attempt to accelerate the growth rate (Hornick et al. 2000). This accelerated growth is identified by being significantly faster than the growth rate of those individuals that have not experienced growth depression and have been kept under the same conditions (Nikki et al. 2004).

Muscle growth is also controlled by the expression of myostatin (Mstn), known as growth and differentiation factor- 8 (GDF-8), member of the transforming growth factor- $\beta$ (TGF- $\beta$ ) superfamily of proteins. However, Mstn is known to inhibit muscle differentiation and growth during myogenesis of vertebrates and functions as a negative regulator of skeletal muscle growth (McPherron et al. 1997). In invertebrates, Mstn has also been shown to restrict muscle growth in the fly Drosophila melanogaster, scallop A. irradians (Kim et al. 2004), and sea cucumber Apostichopus japonicus (Li et al. 2016). In crustaceans, Mstn has been cloned from the lobster Homarus americanus (Kim et al. 2009), the crab Gecarcinus lateralis (Covi et al. 2008), and the shrimp Penaeus monodon and L. vannamei (De Santis et al. 2011; Qian et al. 2013, Zhuo et al. 2017). In the shrimp P. monodon, the Mstn gene was widely expressed across 
all tissues under investigation including the muscle, hepatopancreas, eyestalk, heart, gill, and stomach and presented a high concentration in the muscle after the molt cycle of shrimp (De Santis et al. 2011).

According to $\mathrm{Wu}$ and Dong (2002a), the activity of molting and growth pattern in crustaceans may be related to feeding. Apparently, compensatory growth to some extent contributes to increased frequency of ecdyses by hyperphagia after periods of food restriction. These same authors, studying compensatory growth responses in Chinese shrimp juveniles, F. chinensis, under different temperatures and different diets, found that the period between ecdyses was strongly influenced by food restriction (Wu and Dong 2002b). Also, the consequence of the natural discontinuous growth of crustaceans can be separated into two moments: the first would be the increase in the frequency of ecdyses, that is, in each molt, the old exoskeleton is expelled, and a rapid and extensive growth occurs during a short period before the new exuviae become hardened; the other is the period between ecdyses, during which the exuviae are hard and growth is limited.

In the case of food restriction in a biofloc system, Lara (2016) found high productivity indices in the establishment of $L$. vannamei in a biofloc system during 60 days of cultivation. The study was carried out with six different treatments with a density of 400 individuals $/ \mathrm{m}^{2}$, varying the feed restriction regimes using fixed feed conversion rates. The period of feed restriction and feedback did not affect shrimp growth in the different treatments. There were no statistically significant differences in survival among treatments (means above 95\%). Likewise, no significant differences were found regarding the final weight, weekly growth, and final yield among treatments with higher feed intake. This indicates that a savings of $25 \%$ in the production of shrimp in the biofloc system can be obtained by reducing the use of artificial feed.

In another study, Lara (2016) demonstrated that juvenile shrimps $(1.14 \pm 0.38 \mathrm{~g})$ produced in a biofloc system with artificial feed restriction techniques, with eight different feeding rates, using low feeding rates and divided into two periods, with 21 days of artificial food restriction, and with 29 days with artificial feedback in biofloc showed a partial compensatory growth in the second period and high survival (averages over 95\%), resulting in a savings of $24.79 \%$ in artificial feed.

Foés et al. (2016), working with the post-larvae of 20 days (PL20) of L. vannamei in the nursery stage, using high storage density $\left(2000 \mathrm{PL} / \mathrm{m}^{2}\right)$, tested two different treatments, one long-term of 144 days and one short-term (traditional nursery) of 18 days. Many advantages can be described by using nurseries, such as storage of larger and healthier juveniles in growout ponds, shorter periods of shrimp culture with higher growth rates (Cavalli et al. 2008), and lesser risk of disease introduction and mortality (Samocha et al. 2000). Thus, Foés et al. (2016) sought to study the zootechnical indices for L. vannamei and their compensatory growth after being released in the definitive culture tanks. In this study, it was demonstrated by the values of specific growth rates that after the transfer to the final grow-out ponds with lower storage density, the shrimp presented compensatory growth after a long period of being subjected to stressful storage in the nursery phase. The growth rates were similar to those obtained in traditional cultures without subjecting the PL to induced stress. This study demonstrated that L. vannamei can be maintained in nurseries for long periods of storage at high densities without production losses, since its compensatory growth can be activated when later maintained in a less stressful environment.

As for the environmental issue, Zhu et al. (2016) reported that short periods of fasting caused a decrease in the amount of feces and decrease of phosphorus in the water by leaching of unconsumed feed. After feeding, these short periods of fasting also showed a higher feed 
conversion efficiency, which resulted in a decrease in the phosphorus discharge in the water through the feces when compared to the control group.

These same authors concluded that the establishment of a protocol of feeding cycles with short periods of food restriction has a positive potential in the environmental issue for shrimp farming, since the adoption of a feeding protocol with short periods of fasting can reduce the contribution of nitrogen and phosphorus in the water without apparently affecting the growth of L. vannamei. These results suggest that the use of feeding and fasting cycles, triggering compensatory growth in the shrimp, has a positive effect both from the point of view of production, improving feed conversion, and from the environmental point of view.

\section{Final considerations}

Marine shrimp farming in a biofloc system is a viable reality, technically and economically proven. However, more studies are needed to achieve greater productivity and greater knowledge, so that producers can be assured of an economic activity capable of generating jobs and income with the lowest risks.

The adoption of short periods of feed restriction on shrimp farming in biofloc, such as on Saturdays and Sundays, can save $25 \%$ on feed costs, apart from the savings with staff payroll, since there is no need to maintain a full staffing schedule for feeding activities and other daily activities in a large-scale shrimp culture, and it may be possible to have a simple system of oncall staff with a reduced status, which in Brazil can mean a reduction of $10 \%$ in overtime payments and payroll charges on Sundays, besides reducing costs.

Thus, the adoption of a restriction program on feeding of marine shrimp in a biofloc system may contribute to a reduction in operating costs and reduction of metabolic nutrients dissolved in the water and can lead to a reduction in the number of cycles in which the same water can be reused for consecutive productions.

According to Kuhn et al. (2010) bioflocs can be a suitable ingredient in shrimp feed. This option may offer the shrimp industry a means of mitigating the impacts of aquacultural wastes while producing a substitute for traditional proteins. Furthermore, produced bioflocs could potentially be used as a feed-grade ingredient for a different class of aquatic species, so the added benefit of identifying a suitable replacement for fish meal could ease the pressures on wild fisheries.

Studies on food restriction and compensatory growth in shrimp culture in biofloc could allow an economic increase and become a great ally of socio-environmental advocates, with reduction in operating costs, less use of inputs and pressure on hired labor, and, above all, it may enable future studies in relation to the food and nutritional capacities of the organisms forming the bioflocs and their use as feed for the target species.

According to Avnimelech (2014) and Emerenciano et al. (2012), differences in microorganism profiles or microbial assembly, their benefits for nutrition, microbial ecology of bioflocs, and nitrogen assimilation rates using different carbon source (e.g., glycerol) are knowledge gaps and certainly deserve more investigation. Xu and Pan (2012) believe that further research is needed to better understand pathways and mechanisms of biofloc effects on the nutrition physiology of shrimp and how the bioflocs can be manipulated to maximize shrimp production performance. Last but not the least, Avnimelech (2014) emphasizes the importance of research on biofloc composition under different conditions and the possibility of biofloc manipulation to achieve the desired nutritional content as a supplement. 


\section{References}

Ali M, Nicieza A, Wootton RJ (2003) Compensatory growth in fishes: a response to growth depression. Fish Fish 4:147-190

Ali TES, Martínez-Llorens S, Moñino AV et al (2016) Effects of weekly feeding frequency and previous ration restriction on the compensatory growth and body composition of Nile tilapia fingerlings. Egypt J Aquat Res 42:357-363

Américo JHP, Torres NH, Machado AA et al (2013) Piscicultura em tanques redes: impactos e consequências na qualidade da água. Rev ANAP Brasil 6(7):137-150

Arauco LR, Costa VB (2012) Restrição alimentar no desempenho produtivo da tilápia (Oreochromis niloticus). Com Sci 3(2):134-138

Asaduzzaman M, Wahab MA, Verdegem MCJ et al (2008) C/N ratio control and substrate addition for periphyton development jointly enhance freshwater prawn Macrobrachium rosenbergii production in ponds. Aquaculture 280:117-123

Auster PJ, Stewart LL (1984) Compensatory growth in the bay scallop, Argopecten irradians (L.) J Northw Atl Fish Sci 5:103-104

Avnimelech Y (2014) Biofloc technology: a practical guidebook, 3rd edn. World Aquaculture Society, Baton Rouge

Bauer W, Prentice-Hernedez C, Tesser MT et al (2012) Substitution of fishmeal with microbial floc meal and soy protein concentrate in diets for the pacific white shrimp Litopenaeus vannamei. Aquaculture 342-343:112116

Bavcevic L, Klanjscek T, Karamarko V et al (2010) Compensatory growth in gilthead sea bream (Sparus aurata) compensates weight, but not length. Aquaculture 301:57-63

Cavalli RO, Lehnen TG, Kamimura MT et al (2008) Desempenho de pós-larvas do camarão-rosa Farfantepenaeus paulensis alimentadas com diferentes frequências durante a fase de berçário. Acta Sci Biol Sci 30(3):231-236

Chamberlain G, Avnimelech Y, McIntosh RP et al (2001) Advantages of aerated microbial reuse systems with balanced $\mathrm{C} / \mathrm{N}$. II. Composition and nutritional value of organic detritus. Global Aquacult. Glob Aquacult Adv 4(4):22-24

Comoglio LI, Gaxiola G, Roque A et al (2004) The effect of starvation on refeeding, digestive enzyme activity, oxygen consumption, and ammonia excretion in juvenile white shrimp Litopenaeus vannamei. J Shellfish Res 23(1):243-249

Covi JA, Kim HW, Mykles DL (2008) Expression of alternatively spliced transcripts for a myostatin-like protein in the blackback land crab, Gecarcinus lateralis. Comp Biochem Physiol A Mol Integr Physiol 150:423-430

Crab R, Avnimelech Y, Defoird T et al (2007) Nitrogen removal techniques in aquaculture for a sustainable production. Aquaculture 270:1-14

Crab R, Defoirdt T, Bossier P et al (2012) Biofloc technology in aquaculture: beneficial effects and future challenges. Aquaculture 356-357:351-356

De Santis C, Wade NM, Jerry DR et al (2011) Growing backwards: an inverted role for the shrimp ortholog of vertebrate myostatin and GDF11. J Exp Biol 214:2671-2677

De Schryver P, Defoirdt T, Sorgeloos P (2014) Early mortality syndrome outbreaks: a microbial management issue in shrimp farming? PLoS Pathog 10:10-11

Dobson SH, Holmes RM (1984) Compensatory growth in rainbow trout, Salmo gairdneri Richardson. J Fish Biol 25:649-656

Ekasari J, Angela D, Waluyo SH et al (2014) The size of biofloc determines the nutritional composition and the nitrogen recovery by aquaculture animals. Aquaculture 426-427:105-111

Emerenciano M, Ballester ELC, Cavalli RO et al (2012) Biofloc technology application as a food source in a limited water exchange nursery system for pink shrimp Farfantepenaeus brasiliensis (Latreille, 1817). Aquac Res 43:447-457

FAO (2014) The state of world fisheries and aquaculture (SOFIA) 2014. FAO Fish, Aquac, Rome

Farbridge KJ, Flett PA, Leatherland JF (1992) Temporal effect of restricted diet and compensatory increase dietary intake on thyroid function, plasma growth hormone levels and tissue lipid reserves of rainbow trout Oncorhynchus mykiss. Aquaculture 104:157-174

Ferreira GS, Bolívar NC, Pereira SA et al (2015) Microbial biofloc as source of probiotic bacteria for the culture of Litopenaeus vannamei. Aquaculture 448:273-279

Foés G, Krummenauer D, Lara G et al (2016) Long term and the compensatory growth of white shrimp Litopanaeus vannamei in aquaculture ponds. Lat Am J Aquat Res 44(3):588-594

Gamboa-Delgado J, Oca GARM, Reyes JCR et al (2017) Assessment of the relative contribution of dietary nitrogen from fish meal and biofloc meal to the growth of Pacific white shrimp (Litopenaeus vannamei). Aquac Res 48:2963-2972 
Gao L, Shan H, Zhang T et al (2012) Effects of carbohydrate addition on Litopenaeus vannamei intensive culture in a zero-water exchange system. Aquaculture 243:89-96

Hagen $\varnothing$, Fernandes JMO, Solberg C et al (2009) Expression of growth related genes in muscle during fasting and refeeding of juvenile Atlantic halibut. Comp Biochem Physiol B Biochem Mol Biol 152(1):47-53

Hayward RS, Wang N, Noltie DB (2000) Group holding impedes compensatory growth of hybrid sunfish. Aquaculture 183:299-305

Hopkins JS, Hamilton RD, Sandifer PA et al (1993) Effect of water exchange rate on production, water quality, effluent characteristics and nitrogen budgets of intensive shrimp ponds. J World Aquacult Soc 24:304-320

Hornick JL, Eenaeme CV, Gérard O et al (2000) Mechanisms of reduced and compensatory growth. Domest Anim Endocrinol 19:121-132

Jiwyam W (2010) Growth and compensatory growth of juvenile Pangasius bocourti Sauvage, 1880 relative to ration. Aquaculture 306:393-397

Kim HW, Mykles DL, Goetz FW et al (2004) Characterization of a myostatin like gene from the bay scallop, Argopecten irradians. Biochim Biophys Acta 1679:174-179

Kim BK, Kim KS, CW O et al (2009) Twelve actin-encoding cDNAs from the American lobster, Homarus americanus: cloning and tissue expression of eight skeletal muscle, one heart, and three cytoplasmic isoforms. Comp Biochem Physiol B Biochem Mol Biol 153:178-184

Krummenauer D, Lara GD, al FG e (2013) Sistema de bioflocos: É possível reutilizar a água por diversos ciclos? Panor Aquic 23:40-47

Krummenauer D, Samocha T, Poersch LH et al (2014) The reuse of water on the culture of pacific white shrimp, Litopenaeus vannamei, in BFT system. J World Aquac Soc 45:3-14

Kuhn DD, Boardman GD, Lawrence AL et al (2009) Microbial floc meal as a replacement ingredient for fish meal and soybean protein in shrimp feed. Aquaculture 296:51-57

Kuhn DD, Lawrence AL, Boardman GD et al (2010) Evaluation of two types of bioflocs derived from biological treatment of fish efluente as feed ingredients for Pacific white shrimp, Litopenaeus vannamei. Aquaculture 303:28-33

Lara G (2016) Manejo alimentar de Litopenaeus vannamei cultivado em sistema de bioflocos: efeitos da restrição alimentar e diferentes taxas de arraçoamento sobre os parâmetros zootécnicos. $\mathrm{PhD}$ thesis, Postgraduate Program in Aquaculture, Federal University of Rio Grande - FURG, RS, Brazil

Lara G, Krummenauer D, Poersch LH et al (2012) Sistema de bioflocos. Processos de assimilação e remoção do nitrogênio. Panor Aquic 22:32-37

Li S, Zhou Z, Dong Y et al (2016) Molecular characterization, expression analysis of the myostatin gene and its association with growth traits in sea cucumber (Apostichopus japonicus). Comp Biochem Physiol B Biochem Mol Biol 201:12-20

Lin X-T, Pan J-X, Z-N X et al (2008) Effect of periodic starvation on feeding, growth and defecation of Litopenaeus vannamei. Acta Hydrobiol Sin 32:403-407

Lin Y-C, Chen J-C, Man SNC et al (2012) Modulation of innate immunity and gene expressions in white shrimp Litopenaeus vannamei following long-term starvation and re-feeding. Results Immunol 2(2012):148-156

Maciel JC (2013) Estudo de viabilidade econômica e comercial de produção de camarões marinhos no estado de Minas Gerais em sistema de bioflocos (BFT) em água salgada artificialmente. Monografia. Faculdades Pitágoras, MG, Brasil

Mcpherron AC, Lawler AM, Lee S (1997) Regulation of skeletal muscle mass in mice by a new TGF-beta superfamily member. Nature 387:83-90

Nikki J, Pirhonen J, Jobling M (2004) Compensatory growth in juvenile rainbow trout, Oncorhynchus mykiss (Walbaum), held individually. Aquaculture 235:285-296

Peres H, Santos S, Oliva-Teles A (2011) Lack of compensatory growth response in gilthead seabream (Sparus aurata) juveniles following starvation and subsequent refeeding. Aquaculture 318:384-388

Poersch L, Cavalli RO, Wasielesky WJ, Castello JP, Peixoto SRM (2006) Perspectivas para o desenvolvimento dos cultivos marinhos no estuário da Lagoa dos Patos, RS. Cienc Rural 36(4):1337-1343

Qian Z, Mi X, Wang X et al (2013) cDNA cloning and expression analysis of myostatin/GDF11 in shrimp, Litopenaeus vannamei. Comp Biochem Physiol A Mol Integr Physiol 165:30-39

Samocha TM, Cordova J, Blacher T et al (2000) High-density nursery of Litopenaeus vannamei in white-spot infected area utilizing raceway system with limited water discharge in Ecuador. Global Aquacult. Advocate 3:66-68

Schryver PD, Crab R, Defoirdt T et al (2008) The basics of bioflocs technology: the added value for aquaculture. Aquaculture 277:125-137

Scopel BR, Schveitzer R, Seiffert WQ et al (2011) Substituição da farinha de peixe em dietas para camarões marinhos cultivados em sistema bioflocos. Pesq Agropec Bras 46:928-934 
Sheridan MA, Mommsen TP (1991) Effects of nutritional state on in vivo lipid and carbohydrate metabolism of coho salmon, Oncorhynchus kisutch. Gen Comp Endocrinol 81:473-483

Souza VL, Urbinati EC, Martins MIEG et al (2003) Avaliação do crescimento e do custo da alimentação do pacu (Piaractus mesopotamicus Holmberg, 1887) submetidos a ciclos alternados de restrição alimentar e realimentação. Rev Bras Zootec 32:19-28

Stumpf L, Greco LSL (2015) Compensatory growth in juveniles of freshwater redclaw crayfish Cherax quadricarinatus reared at three different temperatures: hyperphagia and food efficiency as primary mechanisms. PLoS One 10(9):1-9

The World Bank (2013) Fish to 2030: prospects for fisheries and aquaculture. World Bank Report number 83177-GLB. The World Bank, Washington, DC, p 102

Thompson FL, Abreu PC, Wasielesky W (2002) Importance of biofilm for water quality and nourishment in intensive shrimp culture. Aquaculture 203:263-278

Wang Y, Cui Y, Yang Y et al (2000) Compensatory growth in hybrid tilapia, Oreochromis mossambicus x O. niloticus, reared in seawater. Aquaculture 189:101-108

Wang Y, Cui Y, Qin JG et al (2009) Cyclical feed deprivation and refeeding fails to enhance compensatory growth in Nile tilapia, Oreochromis niloticus L. Aquac Res 40:204-210

Wasielesky WJ, Atwood H, Stokes A et al (2006) Effect natural production in a zero exchange suspended microbial floc based super-intensive culture for white shrimp Litopenaeus vannamei. Aquaculture 258:396-403

Wasielesky WJ, Froes C, Fóes G et al (2013) Nursery of Litopenaeus vannamei reared in a biofloc system: the effect of stocking densities and compensatory growth. J Shellfish Res 32(3):799-806

Wu L, Dong S (2002a) The effects of repetitive starvation-and-refeeding cycles on the compensatory growth response in chinese shrimp, Fenneropenaeus chinensis (Osbeck, 1765) (Decapoda, Penaeidae). Crustaceana 74(11):1225-1239

Wu L, Dong S (2002b) Compensatory growth responses in juvenile chinese shrimp, Fenneropenaeus chinensis, at different temperatures. J Crust Biol 22(3):511-520

Wu L, Dong S, Wang F et al (2000) Compensatory growth response following periods of starvation in Chinese shrimp, Penaeus chinensis Osbeck. J Shell Res 19:717-722

Wu L, Dong S, Tian X (2001a) The compensatory growth in the Chinese shrimp (Penaeus chinensis) following starvation. Acta Ecol Sin 21:452-457

Wu L, Dong S, Tian X et al (2001b) The effect of previous feeding regimes on the compensatory growth response in Chinese shrimp, Fenneropenaeus chinensis. J Crust Biol 21:559-565

Xu W-J, Pan L-Q (2012) Effects of bioflocs on growth performance, digestive enzyme activity and body composition of juvenile Litopenaeus vannamei in zero-water exchange tanks manipulating $\mathrm{C} / \mathrm{N}$ ratio in feed. Aquaculture 356-357:147-152

Zhu Z-M, Lin X-T, Pan J-X et al (2016) Effect of cyclical feeding on compensatory growth, nitrogen and phosphorus budgets in juvenile Litopenaeus vannamei. Aquac Res 47:283-289

Zhuo RQ, Zhou TT, Yang SP et al (2017) Characterization of a molt-related myostatin gene (FmMstn) from the banana shrimp Fenneropenaeus merguiensis. Gen Comp Endocrinol 248:55-68 